\title{
The Competing Media Frame Study in One Country of Two System: The Case Study on Scandal of Chen Liangyu
}

\author{
Zhang Yan and Yang Liu
}

\begin{abstract}
This is a content analysis study guided by framing theory based on the unique Chinese society-One Country, Two System. The perspective of framing analysis lies in the different influence made upon the different frames.

This research chooses a controversial issue, Chen Liangyu corruption scandal, as the research case. The mainstream newspapers of Mainland and Hong Kong are selected as research subjects. And then examines how those different newspapers frame this corruption scandal in the following four perspectives: definition of issue, description of issue, reason of corruption, and probability of corruption.

A content analysis on 321 report samples shows that those media did use different frames in their coverage of this corruption scandal. To be specific, in this case, HK media more likely covered the scandal with the frames of power struggle, tip of ice-burg, and dramatic story. On the contrary, Mainland media more likely covered this with the frames of government clean corruption, system fallacy, individual morality, and rotten apple, which illustrated that competing media frame is an influencing factor in discourse formation during Greater China area.
\end{abstract}

Index Terms-Generic framing analysis, competing media frames, corruption scandal.

\section{INTRODUCTION}

\section{A. Research Background}

On June $24^{\text {th }} 2006$, Chen Liangyu, a Chinese mainland high-rank official, who was the Secretary of Shanghai Municipal Committee, the Member of Central Committee of Political Bureau of CPC (Communist Party of China), Central Committee Members of CPC, Deputy to the People's Congresses, was dismissed from all his posts for suspicion of illegal use of Shanghai social security funds, and an investigation was immediately initiated. The case did not conclude until April 22 $2^{\text {nd }}$. According to Xinhua News dispatches, Chen Liangyu committed the crime of accepting bribes and abuse of power and was sentenced to confiscation of 300,000 Yuan of personal property as well as 18-year in prison.

This case lasted for 2-year long and attracted widespread media's speculation and comments around the world. Chinese mainland media even convict him of "seven sins": "embezzlement of public funds", "power-for-money deal", "collusion between government and businessmen", "moral degradation", "philandering", "nepotism", "harboring people who violated laws, regulations and disciplines". However,

Manuscript received August 9, 2014; revised October 15, 2014.

The authors are with University of Macau, Macau (e-mail: 378470334@qq.com, blossom719@hotmail.com). overseas media, represented by Hong Kong media, reported him with "forming cliques", "the friction between local government and central government", and others instead of some of "seven sins". Moreover, two years later, the "much cry, little wool" trial result made the diverse media conducted more controversial coverage on this case.

\section{B. Research Significance}

How to develop and conduct the study of competing media frame is the purpose of this research. Based on the Chen Liangyu corruption scandals introduced above, it is that the Chen Liangyu scandal is a controversial issue for the media. Thus, this study argues that some news frames, used by different media to report the Chen Liangyu scandal, accord with the characteristics of competing media frame. In other words, media will use competing media frames to cover Chen Liangyu scandal. To be specific, the mainstream newspapers from Mainland and Hong Kong are selected as research subjects through content analysis on four frames of coverage: description of issue, reason of corruption, and probability of corruption.

All in all, this paper belongs to the research field of political communication. Based on the media frame functions, this study uses the generic frames to comparatively analyze how the news media report this event with different countries or ideologies in an empirical way. Naturally, this study could formulate the significance as follows. First of all, this study is a response to popularly-concerned issues in Chinese society that could be useful to interpret the Chinese society profoundly. Secondly, this study is to discover the patterns of media to cover issue of similar nature in different areas. More importantly, this study makes a contribution to existing limitations in framing study, especially to explore the study of competing media frame.

\section{LITERATURE REVIEW}

\section{A. News Frame}

Frame is "a common term that has multiple definitions" [1]. Various understandings of framing analysis conduce to its various applications. This paper focuses on how different news media in different areas or with different ideologies frame news events with high similarity. Consequently, this paper belongs to the field of news framing analysis.

News frame is of great importance in news report, choosing what to be included and what to be excluded in a coverage, it can make great influence on audiences to understand public events [2]. News framing analysis is that the attention should be paid to how people construct significance in public life [3]. Theoretically, it emphasizes 
the process of construction, studies and explains the discourse and discourse practice of social actors; as to the analysis methods, it suggests applying various analysis methods to study the actors, actions, acting scene, acting modes, the causes and consequences [4].

Many scholars have discovered that the concept of "frame" is more helpful for examining media coverage [5]. It is because that media frame could be helpful for examining media coverage is that they can be perceive from sender's cognition, text constructed by sender, cognition of receiver, the culture in communication [6]. In short, media frames have the following four functions [6]: defining problem, diagnose causes, moral judgment and suggest remedies. To put it in a nutshell, these four functions will be helpful to identify appropriate frames.

\section{B. Competing Media Frame}

Theoretical expression and research results about news frame both deals with that media (or other participants in the process of communication) often employ different news frame to elaborate upon controversial issues. These disparate, even opposite frames will influence the interpretation of information receivers on the events. In order to compare the news frames used by different media on the same issue, we define these kinds of frames as "Competing Media Frame". Specifically, competing media frames have the following characteristics:

First of all, competing media frames are pertained to issues with high controversy. These frames are different from each other, even opposite. Secondly, the determinants of disparity among competing media frames lie in different ideologies, social values, market and profit inclinations, professional conceptions, and operating modes among media. Last but not least, the most significant competing media frames are from various media which could cover the same subject audiences. Those frames could consciously or unconsciously compete for the attention of the same subject audiences.

The most relevant research comes from Chen Huailin, a professor of University of Macau. Chen [7] has been making a series of studies on comparison between the media frames and audience frames in recent two years, such as, frames as well as their consequences of Mainland and Hong Kong media covering the "Lip-synching" in Beijing Olympics Opening Ceremony and the "Poisonous Milk" in Mainland, China; and frames as well as their consequences of Mainland and Macau media covering the "Ou Wenlong Corruption" case.

Li and Tang [8] also carried out a framing analysis concerning a Chinese issue. This study content analyzes how national and regional newspapers in the United States frame the coverage about the Chinese product recall in 2007. The different perspectives from America and China become the source of the identification of frame for this study. Naturally, the various opinions conduce to the formation of conflict frames. Compared with the case mentioned above, there are no differences in essence in research subjects as well. Thus the result of this study demonstrates that both local and national media in America are still dominated by coverage from the U.S. perspectives, in contrast Chinese sources are less likely to be cited. So the competing media frames can hardly be generated in American newspapers.

Another similar study performed by Luther and Zhou [9] paid the attention to the issue of SARS in China. It also chose the newspapers with different ideologies as the research subjects to compare their news frames when reporting the SARS. They were New York Times, Washing Post, People's Daily, and China Daily. Based on the Western news media systems [10], the researcher developed five news frames: economic consequences, responsibility, conflict, leadership, and human-interest. This study argued that news frames adopted in Chinese press were similar to those found in Western ones under the influence of Western news values and practices. The final results of this paper testified that the major news frames often used in the U.S. press were, indeed, self-evident in the Chinese news content, which indicated Western news values adopted by the Chinese journalists have penetrated into their writings. That means these five news frame adopted and employed by both Chinese and American newspapers will be appropriate as competing media frames to compare the coverage of different media. Hence, those frames were worth being reference for the similar studies. The limitation of this paper lies in no further exploration on how those frames used by different media cover the SARS in detail.

The most recently competing media frame study was: Competing Media Frames after the Santa Barbara Shootings: Which Narrative "Wins?" It was done by Lindsay Hoffman [11], professor of Communication and Political Science, University of Delaware. This study focuses on the case of Santa Barbara Shootings. In this study they concludes that competing frame is not a choice, it is unavoidable. They chose CBS News, USA Today, UK's Guardian and Washington Post as their research subjects. What's more, they also include the opinion forums in their study, such as twitter. The researchers refined two types of frames in this study: "game" frame and "madman" frame.

However, as mentioned by Chen Huailin, who have been systematically studied competing media frame, according to his research, competing media frames are from those media with different ideology or cultural background but covering the same controversial issue, and those coverage could be received by the same audience. Based on this conclusion, Lindsay's study lacked the same receiving audience.

\section{Scandal News Framing}

Researches on competing media frames are always connected with the so-called "scandals" [7]. For example, the research of media news frames and audience interpreting frames focused on the "Zippergate" of former U.S. president Clinton [12]; the frames were used by church and media in the case of "Clerge Sexual Abuse" [13]. "Scandals are sporadic phenomena coming to light at specific points in history, in specific environments. Central to the idea of a scandal is "the admission or revelation of illegal or unethical behavior" [14]. Scandals, to be treated as news events and formerly secret peccadilloes media stories brought to light, are possible with the intervention of mass media [14]. That is the reason that scandal study can attract the researchers' attention. However, few studies stress on the scandal by using faming analysis, especially on corruption scandal. That 
also accounts for why the corruption scandal becomes the focus of this study. Some literature of framing analysis on scandal will be reviewed in the following section.

Julie and Ivana [14] conducted a research which examined how the media frames of Clinton-Lewinsky scandal, especially the frame of sex scandal, affected audiences. With the combination of framing analysis and agenda-setting, this paper carry out the study using content analysis as methodological approach. The concrete operations of this paper for studying media reports are: with two famous newspapers, New York Times and Washington Post, as the study subjects, the same amount of news stories were picked on this topic randomly. Based on "list of frame" [15], researchers developed a series of frames, such as, sex scandal, partisan battle, morality, strategy, and impact.etc. In particular, the impact frame had been categorized as impacton Presidency, impact on Lewinsky, impact on First Family, and impact on others. This study found that there was difference between these two media which considered Clinton-Lewinsky scandal as sex scandal/adultery. Naturally, the frames mentioned in this paper are worth being for future reference.

Meanwhile, another scholar, Kenshi [12] discussed how news media framed Clinton-Lewinsky scandal as well. Operational method in this paper is still content analysis. The differences are that the subjects in this paper are three authoritative TV media with a long-time study. Moreover, this paper use "emphasis framing" [12] to identify frame, which is the stories that this study collected could be coded as being framed as "strategy", "issue", or "other". "Strategy frames discuss news in terms of who is winning or losing, ahead or behind, or discuss campaign mechanics and tactics." [12] On the other hand, "Issue frames discuss the background of an issue or a candidate's, politician's, party's, or interest group's position on an issue "[12]. Simply speaking, they have different emphasis on the news content, so that they already have their own competitive attributes. "Other frame" means the frame of a unit could be categorized as neither "strategy frame" nor "issue frame" [12]. The results found that each media have astonishingly same tendency, which means all research subjects framed the Clinton-Lewinsky scandal stories as a public matter; the framing of the scandal coverage overall was more issue-based than strategy-based. This also proves that media with the same ideology have the slightest disparity in the adoption of frames. Therefore, media with different ideologies as research subjects are still more suitable.

Through the review of the various cases above, firstly, the study of the competing media frame has drawn the attention of scholars, but the studies concerning scandal research conducted by competing media framing analysis is limited. Secondly, although different issues have different specific frames, some of the media frames could be identified across different issues mentioned above, such as, definition, judgments, suggestion, which respond to the functions of media frames. Therefore, functions of media frames explored by Entman [6] could help us find appropriate frames. Finally, this study focuses on both Chinese issues and scandal research, so frames developed by the studies above, such as, institution, individual, morality, impact, and partisan battle etc. are worth being for reference.

\section{Methodology}

\section{A. Selecting Research Subjects}

It should be noticed that China government policy on the media within Guangdong province is different with other provinces: Cantonese can read and watch the news reports from both Mainland and HK (Hong Kong) media. As overseas media, HK media have great differences on ideologies, attitudes, stance, or values with Mainland media. Thus, influential Guangdong media and Hong Kong media, as the representatives of Mainland media and overseas media, are selected as the research subjects in this paper. However, in view of the particularity of media policy in Guangdong, Guangdong media may not represent all Mainland media. Considering that Shanghai is geographically close to Guangdong and that Shanghai media also have powerful influence like Guangdong media, the media in Shanghai areselected as the supplemental research subject represented Mainland media. Therefore, Guangdong and Shanghai media, as the representative of mainland media, and Hong Kong media, as the representative of overseas media, are selected as the research subjects to examine their differences in using the news frames to report the Chen Liangyu scandal. To be specific, among these three cities, two major print media in each city will be selected as the research subjects. They are: HK newspapers including Ming Po and Apple Daily, Guangzhou newspapers including Guang Zhou Daily, and Southern Metropolis Daily, and Shanghai newspapers including Liberation Daily, and Xinmin Evening News.

\section{B. Research Methods}

The current framing analysis frequently utilizes three specific operational ways below. The first kind of approach is "a text based, non-quantitative analysis" [16], [17]. The second is that a number of studies code frames as variables in a quantitative way with content analysis including the inductive and deductive identification of frames [9], [18], [19]. Still, some of those quantitative studies would utilize the "computer-assisted frame analysis" [20]. The quantitative content analysis will be chose as the method to analyze this research. Considering that all of research subjects will be the print media, definitely, the unit of analysis of this study will focus on every piece of news articles from six representative newspapers.

\section{Identification of News Frames}

How to find those multiple frames for the content analysis is the following problem to be solved. Generic framing analysis [21] and media frame functions [6], [22] are the theoretical foundations of identification of frames in this study. In process of identification, this study also refers to the frames identified by the studies on scandal research and Chinese issues, which have been discussed in the literature review. After reading a great number of news stories on the Chen Liangyu corruption scandals, there are 4 sets of competing media frame drawn from the coverage of the six representative media in total. They are Nature, Responsibility, Scope, and Human Interest. 
Nature developed by this study is the frame on how media define the events. It could be refined as government clean corruption or power struggle. Responsibility frame presents "an event or problem in such a way as to attribute responsibility for its cause or solution to either the government or to an individual or group" [19]. As for the corrupt reasons, the opinions of media concentrate on the system fallacy or individual morality. Based on the ability of the media frames to diagnose the event [6], this study explores another frame, Scope, which accounts for the probability of other corrupt officials. Different media will polish Scope as rotten apple or tip of ice-burg. A human interest frame, as Valkenburg, Semetko and De Vreese [23] put it, "brings an individual's story or an emotional angle to the presentation of an event, issue, or problem" (p. 551).

Based on the discussion above, news frames used in this study will be identified with a 3-point likert scale.

\section{Data Collection}

The data collecting will be by means of the news searching tool--"Wisenews Database" which is an e-database for finding the news articles including more useful information of news, such as the content of news, the publishing data of news, the name of the author of news, the characters of news, and the layout of news. According to the exposure's progression of these two scandals, the range of searching dates will respectively focus on the period between 2006.9.25 and 2008.9.30, as is right for the Chen Liangyu corruption scandal. Finally, in order to insure the accuracy and precision of the research, the searching keywords should be only setted as "Chen Lianyu". Certainly, this large-scale search may cause that some news partly not meeting the purpose of this paper will be selected into this research, but they will be removed in analysis part.

\section{HYPOTHESES}

According to the methodology discussed above, this study argues that there are significantly different tendencies between overseas and Mainland media towards framing Chen Liangyu corruption scandals. The media in Mainland and Oversea will be inclined to choose different news frames to define the nature of Chen Liangyu's corruption scandal, to explain reasons for his corruption, to diagnose the potential corruption rate, to describe this issue.

HA1: HK media are more likely to cover the corruption scandal of Chen Liangyu with the frame of power struggle.

HA2: HK media are more likely to cover the corruption scandal of Chen Liangyu with the frame of system fallacy.

HA3: HK media are more likely to cover the corruption scandal of Chen Liangyu with the frame of tip of ice-burg.

HA4: Mainland media are more likely to cover the corruption scandal of Chen Liangyu with the frame of government clean corruption.

HA5: Mainland media are more likely to cover the corruption scandal of Chen Liangyu with the frame of individual morality.

HA6: Mainland media are more likely to cover the corruption scandal of Chen Liangyu with the frame of rotten apple.
HA7: HK media are more likely to cover the corruption scandal of Chen Liangyu with the frame of dramatic story.

\section{RESUlts of DAta ANALYSIS}

Based on "Wisenews Database" and the relevant key words, there are 859 news reports about Chen Liangyu. After being examined carefully, there are 321 reports pertaining to Chen Liangyu's corruption scandal. Then, this paper will make descriptive and explanative analysis of these 321 news reports.

\section{A. Descriptive Findings}

According to Table I in terms of area, Mainland reports about this corruption scandals account for $31.8 \%$. Among the three cities, the Hong Kong news reports on the case account for $68.2 \%$. Guangdong media's reports on the case account for $19.6 \%$ that is more than those in Shanghai, which demonstrates the particularity of Guangzhou province. In particular, unlike the other two city media, Shanghai media laid more emphasis on Chen Liangyu's case.

As for the six representative newspapers, two print media agencies in Hong Kong have similar percentage, which is about 30\%. The statistic shows that Hong Kong media have larger amount of reports on Cheng Liangyu's case than Mainland media, but nearly same amount with the Southern Metropolis Daily, a Guangzhou newspaper. For the two print media in Guangdong, Southern Metropolis Daily apparently has higher percentage than CPC newspaper in Guangzhou. At the same time, with the percentage of $13.1 \%$, it becomes the Mainland print media with the largest amount of reports on the case. Similarly, Xinmin Evening News in Shanghai also has the more reports than Liberation Daily, a Party newspaper in Shanghai. It demonstrates that on one hand, Party newspaper's reports number on corruption is absolutely less than other commercial newspaper in same city; on the other hand, it shows that Guangzhou media comparatively provides more information to audiences than other Mainland media on this scandal.

TABLE I: AMOUNT AND PERCENTAGE OF DifFERENT SOURCE OF INFORMATION

\begin{tabular}{cccc}
\hline \hline & Source of Information & Amount & $\begin{array}{c}\text { Percentage } \\
(\%)\end{array}$ \\
\hline \multirow{2}{*}{ Area } & Oversea & 219 & 68.2 \\
& Mainland & 102 & 31.8 \\
& Hong Kong & 219 & 19.6 \\
& Guang Zhou & 63 & 12.1 \\
Newspaper & Shang Hai & 39 & 31.8 \\
& Apple Daily & 117 & 36.4 \\
& Guang Zhou Daily & 21 & 6.5 \\
& Southern Metropolis Daily & 42 & 13.1 \\
& Liberation Daily & 16 & 5.0 \\
& Xinmin Evening News & 23 & 7.2 \\
& Total & 321 & 100.0 \\
\hline \hline
\end{tabular}

\section{B. Explanative Findings}

By descriptive analysis, this study finds that there are significant differences on how the media from two areas deal with story type, news layout and characters length of this corruption scandal. Correlation analysis that this paper 
conducts is used to further reveal the difference on news stories in two areas media.

Table II shows the correlation level between the reports of Chen Liangyu corruption scandal and diverse news frames. In light of the statistics, firstly those seven frames have high correlation with reports both from two areas, within which the most remarkable correlation is the frames of government clean corruption and dramatic story. Secondly, it is found that Mainland media are more apt to the frames of government clean corruption, system fallacy, individual morality and rotten apple, while overseas media prefer the frames of power struggle, tip of ice-burg, and dramatic story.

At the same time, this study finds that there is something in common when the seven frames are employed by media from two areas to report Chen Liangyu's case. The more media use the frame of government clean corruption, the more they will use the frames of system fallacy, individual morality, and rotten apple, but the less they will use the frame of dramatic story. Meanwhile, the more the frame of power struggle is used, the more the frame of dramatic story will be used, but the less the frame of rotten apple will be used. And the more the frame of system fallacy is applied, the more the frame of individual morality will be applied. The more the frame of individual morality is used, the more the frame of tip of ice-burg will be used, but the less the frame of rotten apple will be used. When the frame of rotten apple is used, both of the frames of tip of ice-burg and dramatic story will be less used. At last, the more the frame of tip of ice-burg is used, the more the frame of dramatic story will be used only.

TABLE II: CORRELATION ANALYSIS ON CHEN LIANGYU CORRUPTION SCANDAL

\begin{tabular}{|c|c|c|c|c|c|c|c|c|}
\hline & $\begin{array}{c}\text { Area } \\
\text { Oversea }=1 ; \\
\text { Mainland }=2\end{array}$ & $\begin{array}{c}\text { Frame } \\
1\end{array}$ & $\begin{array}{c}\text { Frame } \\
2\end{array}$ & $\begin{array}{l}\text { Fram } \\
\text { e } 3\end{array}$ & $\begin{array}{c}\text { Frame } \\
4\end{array}$ & $\begin{array}{c}\text { Frame } \\
5\end{array}$ & $\begin{array}{c}\text { Frame } \\
6\end{array}$ & $\begin{array}{c}\text { Frame } \\
7\end{array}$ \\
\hline Frame 1 & $.436^{* *}$ & 1 & & & & & & \\
\hline Gov. Clean & & & & & & & & \\
\hline Corruption & & & & & & & & \\
\hline Frame 2 & $-.301 * *$ & & & & & & & \\
\hline Power Struggle & & & & & & & & \\
\hline $\begin{array}{l}\text { Frame } 3 \\
\text { System Fallacy }\end{array}$ & $.136^{*}$ & $.221^{* *}$ & & & & & & \\
\hline $\begin{array}{l}\text { Frame } 4 \\
\text { Individual } \\
\text { Morality }\end{array}$ & $.156^{* *}$ & $.178^{* *}$ & & $.137 *$ & & & & \\
\hline Frame 5 & $.213^{* *}$ & $.178 * *$ & $-.149 *$ & & $-.190 *$ & & & \\
\hline Rotten Apple & & & * & & * & & & \\
\hline Frame 6 & $-.238 * *$ & & & & $.254^{* *}$ & $-.825^{*}$ & & \\
\hline Tip of Ice-burg & & & & & & $*$ & & \\
\hline Frame 7 & $-.429 * *$ & $-.211 *$ & $.404 *$ & & & $-.328 *$ & $.328 * *$ & 1 \\
\hline Dramatic Story & & * & * & & & * & & \\
\hline
\end{tabular}

${ }^{*} p<0.05, * * p<0.01, * * * p<0.001, n=321$

\section{CONCLUSION AND DISCUSSION}

By adopting seven generic frames identified in competing media frame study, this paper comparatively analyzes how mainstream print media, which come from different Chinese areas with different ideologies, competitively frame controversial corruption scandals. At length, a total of 321 news articles as research samples are analyzed in descriptive and explanatory way.

It is found that $\mathrm{HK}$ media more likely covered this scandal with the frames of power struggle, tip of ice-burg, and dramatic story. On the contrary, Mainland media more likely covered it with the frames of government clean corruption, system fallacy, individual morality, and rotten apple. Thus, except hypothesis A2, other hypotheses about Chen Liangyu's case are validated. In other words, two areas media had competing media frame on the Nature, Scope, and Human Interest. However, the frames of system fallacy and individual morality more appeared in the coverage of Mainland media, which also proved that the Responsibility of the Chen Liangyu's corruption was very controversial in Mainland media coverage.

Research findings show that there are significant differences in coverage on a domestic controversial issue between HK and Mainland media. Instead, there is insignificant disparity when covering controversial issue that happened overseas. The findings on Chen Liangyu issue actually respond to what the previous researches suggest regarding the traditional media in Mainland, China: sensitive content is more subject to ideological control by the CPC [2], [23].

All in all, on the one hand, this study explores the study of competing media frame which is a contribution to existing limitations in Framing Study. As limited by time, this paper, focusing only on the print media in Shanghai, Guangzhou and Hong Kong, does not analyze the perspectives from more influential TV media and emerging online media. Therefore, further study should include more media. Meanwhile, the current study confined in the field of framing building has limitations in the influence study of competing media frame. Accordingly, further study should stress on how competing media frame influences their audiences.

\section{ACKNOWLEDGMENT}

We would like to show my deepest gratitude to my professors from University of Macau, Professor Chen Huailin and Professor Wu Mei, respectable, responsible and resourceful scholars, who has provided me with valuable guidance in every stage of my study. Without their enlightening instruction, impressive kindness and patience, we could not have continued my study. Their keen and vigorous academic observation enlightens me not only in this paper but also in my future study.

\section{REFERENCES}

[1] J. W. Tankard, L. Hendrickson, J. Silberman, K. Bliss, and S. Ghanem, "Media frames: approaches to conceptualization and measurement," presented at the annual meeting of AEJMC, Boston, August, 1991.

[2] Z. Pan and G. M. Kosicki, "Framing analysis: an approach to news discourse," Political Communication, vol. 10, pp. 55-75, 1993.

[3] Z. Pan, "Framing analysis: toward an integrative perspective, improvising reform activities: the changing reality of journalistic practice in China," in Power, Money, and Media: Communication Patterns and Bureaucratic Control in Cultural China, C. C. Lee ed., pp. 68-111, Evanston, IL: Northwestern University Press, 2000 and 2006.

[4] K. Burke, On Symbols and Society, J. R. Gusfield ed., Chicago, IL: The University of Chicago Press, 1989.

[5] J. N. Druckman, "The implications of framing effects: who can frame?" The Journal of Politics, vol. 23, pp. 225-256, 2000.

[6] R. M. Entman, "Framing: Toward clarification of a fractured paradigm," Journal of Communication, 1993.

[7] H. Chen, "Impact of interpreting frames on attitude to controversial issue: case of 'replacement singing' in Beijing Olympic," presented at the Annual Conference of ICA, Singapore, June, 2010.

[8] H. M. Li and L. Tang, "The representation of the Chinese product crisis in national and local newspapers in the United States," Public Relation Review, vol. 35, issue 3, pp. 219-225, 2009. 
[9] B. V. Gorp, "Where is the frame? Victims and intruders in the belgian press coverage of the asylum issue," European Journal of Communication, vol. 20, pp. 485-550, 2005.

[10] P. M. Valkenburg, H. A. Semetko, and C. H. de Vreese, "The effects of news frames on readers' thoughts and recall," Communication Research, vol. 26, no. 5, pp. 550-69, 1999.

[11] L. Hoffman. (June 2, 2014). Competing Media Frames After the Santa Barbara Shootings: Which Narrative 'Wins?' [Online]. Available: http://www.huffingtonpost.com/lindsay-hoffman/competing-media-fr ames-elliot-rodger_b_5414366.html

[12] K. M. Kenshi, "The framing of network news coverage during the first three months of the Clinton-Lewinsky scandal," in Images, Scandal, and Communication Strategies, E. Robert, J. Denton, and R. L. Holloway eds., 2003

[13] T. D. Lytton, "Tort claims, framing, and agenda access: the case of clergy sexual abuse litigation," presented at the Annual Meeting of Law \& Society, 2005.

[14] Y. Julie and S. Ivana, "Revisiting the Clinton/Lewinsky scandal: the convergence of agenda setting and framing," J\&MC Quarterly, vol. 80 , no. 3, pp. 567-582, Autumn, 2003.

[15] J. W. Tankard, L. Hendrickson, J. Silberman, K. Bliss, and S. Ghanem, "Media frames: approaches to conceptualization and measurement," presented at the Annual Meeting of AEJMC, Boston, August, 1991.

[16] D. Downs, "Representing gun owners: frame identification as social responsibility in news media discourse," Written Communication, vol. 19, pp. 44-75, 2002.

[17] L. R. Tucker, "The framing of calvin klein," Critical Studies in Mass Communication, vol. 15, summer, 1998.

[18] Iyengar and Shanto, "Is anyone responsible?" How Television Frames Political Issues, Chicago, IL: The University of California Press, 1991

[19] A. Simon and M. Xenos, "Media framing and effective public deliberation," Political Communication, vol.17, pp.363-376, 2000.
[20] A. E. Jasperson, D. V. Shah, M. Watts, R. J. Faber, and D. P. Fan, "Framing and the public agenda: media effects on the importance of the federal budget deficit," Communication, vol. 15, pp. 205-224, 1998.

[21] C. H. de Vreese, "News framing: theory and typology," Information DesiNgne Jwous rfnraal, vol. 13, no. 1, pp. 51-62, 2005.

[22] R. M. Entman, Projections of Power: Framing News, Public Opinion, and U.S. Foreign Policy, Chicago: University of Chicago Press, 2004

[23] T. K. Chang, J. Wang, and C. H. Chen, "News as social knowledge in China: the changing worldview of Chinese national media," Journal of Communication, vol. 44, no. 3, pp. 52-69, summer, 1994.

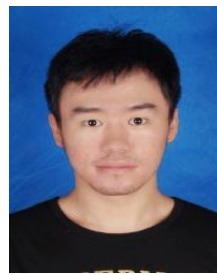

Zhang Yan is a Ph.D. candidate. He studies at University of Macao, majoring in communication study, supervised by Prof. WU Mei. He received his master degree in new media and communication from University of Macao in 2010, supervised by Prof. CHEN Huailin; and received his bachelor degree in director of broadcasting and television from Communication University of China.

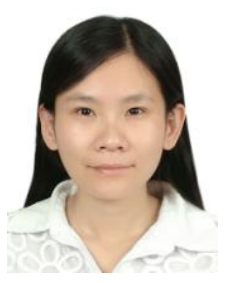

Yang Liu is a current Ph.D. student in Communication Department, University of Macau, supervised by Prof. Chen Huailin. Her research interests include news coverage framing studies, health communication studies and also cross-regional communication. 